\title{
Cefbuperazone Sodium
}

National Cancer Institute

\section{Source}

National Cancer Institute. Cefbuperazone Sodium. NCI Thesaurus. Code C98217.

The sodium salt form of cefbuperazone, a semi-synthetic second-generation

cephalosporin with antibacterial activity. 